\title{
LA INVENCIÓN DE ALDANA
}

Sobre Felipe Aldana. Nadie es responsable. Rosario: Río Ancho, 2015. 167 pp.

Marcelo Britos

UNR

Cuando Camus comenzaba a percibir las repercusiones de El extranjero y editaba La peste, y seis años después de que Borges tradujera al español Las palmeras salvajes de William Faulkner, Felipe Aldana daba inicio a los borradores de su primera novela y único intento narrativo que permaneció en las sombras hasta que la editorial Río Ancho decidió, con mucho acierto, incluirla en su colección Palabras recobradas.

Sucedían también otras cosas. El mundo aún convulsionado por el fin de la guerra comenzaba su pasaje a la segunda mitad del siglo XX, marcada por la división geopolítica y económica de la guerra fría, dos miradas antagónicas que pretendían arrebatarse entre sí la voluntad de los hombres. Mientras tanto, el país también atravesaba transiciones que más tarde alcanzarían la altura de hito. Surgía un segundo movimiento social, de carácter popular, que marcaría para siempre la vida política argentina. En resumen, un contexto internacional y vernáculo que no sería indiferente al autor en el proceso creativo. 
Es siempre auspiciosa la aparición de una obra inédita cuando se trata de un autor fundamental como es el caso de Felipe Aldana. Pareciera que es ya una condición de su obra llegar tardíamente, como ocurrió con su poesía completa, editada recién en el año 2001. Pero aquí se redobla la novedad, porque se trata de un territorio que hasta hoy parecía ajeno para Aldana.

Sin embargo, no se debe buscar en Nadie es responsable las señales de una novela canónica, ni mucho menos ubicarla en la biblioteca de sus contemporáneos. Como afirma Osvaldo Aguirre en el estudio preliminar, se trata de una propuesta atípica, como lo era también su deslumbrante obra poética. Es, en definitiva, una invención que se constituye en la extensión de su condición de poeta sobre otro género, contaminándolo y llevando esa visión a una zona que trasciende cualquier clasificación: ser quizá la continuación de sus poemas en otra dimensión literaria, una narración para nada convencional, con musicalidad e imágenes más cercanas a lo lírico que a lo épico.

Es posible esbozar una descripción de la estructura de Nadie es responsable. De hecho el estudio preliminar lo hace, no así encontrar una unidad argumental que acerque al lector a un primer roce con la trama. Es en esa necesidad caótica de contar y de desembozar pensamientos y sensaciones, donde Aldana se aleja de la narración convencional para ofrecer una construcción de puro lenguaje poético. Si bien reproduce ciertos guiños de la narración contemporánea, como el punto de vista múltiple o la irrupción del elemento fantástico (representada por un "duendecillo" que sirve a la vez de recurso cohesivo de las variaciones anárquicas en las que suele 
entrar la novela), el clima de la historia está siempre marcado por cierto tono de denuncia, por momentos forzado y panfletario: en la primera parte, de los abusos de poder del peronismo, y del estalinismo luego, en una extraña "entrevista" que mantiene el duendecillo con el propio Stalin, al comienzo de la segunda parte.

La muerte de un docente con ideas socialistas (el mismo autor supo enrolarse en el Partido Socialista, por esos años) es el hecho con el que se cierra la primera parte, habilitando el intertexto con la película de Giordana, I cento passi, que cuenta la vida y muerte de Peppino Impastato, un joven comunista asesinado por denunciar los vínculos entre la mafia y la clase política siciliana. En los capítulos finales, un estudiante universitario también pone en juego sus ideas políticas, de la misma forma en la que el autor interpela allí las formas establecidas de la expresión literaria, es decir, reproduce ese viejo debate pero de una forma explícita, como lo hace subrepticiamente en el tono total de la obra.

Como anticipando una tradición de novelistas argentinos que presentaron en su narrativa el díptico provincia - ciudad (Conti y Kordon, para nombrar los más significativos), los capítulos iniciales transcurren en un pueblo de provincia. Es válido decir que Aldana comenzó a escribir la novela en su estancia en General Rojo, en la Provincia de Buenos Aires. El trabajo cierra en una Rosario urbana, por momentos recurriendo a señales demasiado obvias para lograr efectos de realidad, como la referencia al clásico del fútbol rosarino, o a sitios característicos como el barrio Alberdi. 
Cuando la revista El lagrimal trifulca publicó en los 70' su Poema materialista ("iTodo se registra en este libro mayor!/ Los juguetes/ y la ausencia de juguetes/ Y todo con su precio: / la escarlatina, / el enojo, / la alegría, / el dolor, / la pesadilla, / los centavos...") se avistaba una voz singular que condensaba en su entrega fulgurante y poderosa, las inquietudes vanguardistas del autor y sus preocupaciones sociales. Todo esto en un lenguaje que por coloquial y desenvuelto, no dejaba de ser profundo. Nadie es responsable no escapa a estas señales, propias de la poesía de Aldana, aunque si sea esquiva a todo lo que el lector suele esperar de una novela. El descubrimiento permanente de la obra del autor, y la genialidad que carga en su estilo, hacen de este texto una pieza de ineludible lectura. 